\title{
SOLID OBJECTS
}





\section{SOLID OBJECTS}

MODERNISM AND THE TEST

OF PRODUCTION

DOUGLAS MAO

PRINCETON UNIVERSITY PRESS

P R I N C E T O N, N E W J E R S Y 
Copyright (C) 1998 by Princeton University Press

Published by Princeton University Press, 41 William Street,

Princeton, New Jersey 08540

In the United Kingdom: Princeton University Press, Chichester, West Sussex

All Rights Reserved

\section{Library of Congress Cataloging-in-Publication Data}

Mao, Douglas, 1966-

Solid objects : modernism and the test of production / Douglas Mao.

p. $\quad \mathrm{cm}$.

Includes bibliographical references and index.

eISBN 1-4008-0507-4

1. Modernism (Literature) 2. European literature-20th century-

History and criticism. 3. Material culture in literature. I. Title.

PN56.M54M36 $1998 \quad 809^{\prime} .9112 — \mathrm{dc} 21 \quad 98-11863$ CIP

This book has been composed in Times Roman

$\mathrm{http}: / /$ pup.princeton.edu 
To Evelyn Schwarz, my mother 

Ein Leben ward vielleicht verschmäht, wer weiß? Ein Glück war da und wurde hingegeben, und endlich wurde doch, um jeden Preis, dies Ding daraus, nicht leichter als das Leben und doch vollendet und so schön als sei's nicht mehr zu früh, zu lächeln und zu schweben.

(A life perhaps was spurned, who knows? A chance at happiness was there and given up, and yet finally, at whatever price, this thing grew out of it, not easier than life and yet completed and so perfect - as if it were no longer too soon to laugh and soar.)

R. M. Rilke, "Die Spitze" ("The Lace"), translated by Edward Snow

In our Father's house there are many mansions, they taught, and there alone will the incompatible multitudes of mankind be welcomed and soothed. Not one shall be turned away by the servants on that verandah, be he black or white, not one shall be kept standing who approaches with a loving heart. And why should the divine hospitality cease here? Consider, with all reverence, the monkeys. May there not be a mansion for the monkeys also? Old Mr. Graysford said No, but young Mr. Sorley, who was advanced, said Yes; he saw no reason why monkeys should not have their collateral share of bliss, and he had sympathetic discussions about them with his Hindu friends. And the jackals? Jackals were indeed less to Mr.

Sorley's mind but he admitted that the mercy of God, being infinite, may well embrace all mammals. And the wasps? He became uneasy during the descent to wasps, and was apt to change the conversation. And oranges, cactuses, crystals and mud? and the bacteria inside Mr. Sorley? No, no, this is going too far. We must exclude someone from our gathering, or we shall be left with nothing.

E. M. Forster, A Passage to India 
